\title{
An Essay on AfonsoPão: An Example of the Practice of Conventional Medicine and Ayurveda, in Portuguese India (XVIII Century)
}

\author{
Paulo Nuno Martins \\ Inter University Center for History of Science and Technology, New University of Lisbon, Campus of Caparica, Building VII, Floor 2, \\ 2829-516 Caparica, Portugal
}

\begin{abstract}
The aim of this essay is to describe the historical context that contributed to the fact that Portuguese physician IgnácioCaetano AfonsoPão, born in Portuguese India (XVIII century), had both knowledge of conventional medicine (taught by physicians from Portugal) and Ayurveda (taught by natives Indians) that allowed him to heal his patients more effectively.
\end{abstract}

Keywords: Afonso Pão, conventional medicine, Ayurveda, Portuguese India (XVIII century)

\section{Introduction}

The "Old Goa" founded in the XV century by the Sultanate of Bijapur was conquered by Afonso de Albuquerque, in 1510. Thus, from the XVI century, the Portuguese come into contact with Indian culture, having compiled several books on medicinal substances in Portuguese India, such as "Suma Oriental" Medicine (by Tomé Pires), "Colloquiums of Simple and Drugs of India" (by Garcia da Orta) [1]. In the XVI century, in the College of St. Paul of the Arches, in Goa (capital of the Portuguese State in India), the Jesuits taught medicine together with theology, mathematics, astronomy, etc. The administration of the Royal Hospital of Goa, founded by Afonso de Albuquerque, was also carried out by the Jesuits. This hospital enjoyed a high reputation until the late XVII century [2]. Meanwhile, between 1580 and 1640, the Portuguese Crown under the Spanish rule, lost the wealth of Portuguese India, which contributed to the decay of the medical-sanitary conditions with which the patients were treated at the Royal Hospital of Goa. Furthermore, the commercial competition of the Dutch and British also contributed to the decadence of this Hospital. With the independence of 1640, the Portuguese Crown decided to elect Brazil as the main Portuguese to which spices of Portuguese India were sent in order to compete with the Dutch and British [3]. So, this essay intends to show the contribution of the Portuguese and Goan physician IgnácioAfonsoPão for conventional medicine and Ayurveda, in Portuguese India (XVIII century).

\section{Methods}

In this brief communication, the 16 main books and scientific articles were selected, based on the "impact factor", in order to give the reader a global idea on the subject in question, but maintaining the scientific rigor.

\section{AfonsoPão and the practice of conventional Medicine and Ayurveda, in Portuguese India (XVIII century)}

From the XVI century, the contact with Western culture led to the emergence of unknown diseases in India, such as syphilis, tuberculosis, for which Ayurveda does not have a response as effective as conventional medicine [4]. Thus, particularly under British rule, the teaching and practice of Ayurveda declined [5].

On the other hand, in 1678, Cristóvão de Sousa Coutinho asked the Portuguese king, "two or three masters" to teach conventional medicine to natives of Portuguese India, due to the degradation of the conditions mentioned, in the Royal Hospital. At this time, this hospital was headed by Indian natives, with poor preparation in conventional medicine [6].In 1759, several epidemics also devastated the population of "Old Goa" which led the Portuguese Viceroy to move to Pangim ("New Goa"). So, the"Old Goa"lost the official capital status of the Portuguese state of India, in 1843. In 1703, the physicianCipriano Valadares went to Goa in order to teach conventional medicine at the Royal Hospital. In 1735, the Portuguese physicianLuís da Costa of Portugal studied the causes of the epidemics of Portuguese India and implemented a rudimentary course of conventional medicine. He examined AfonsoPão who was the first Goan native to obtain a doctor's degree and so, he is known as the "Aesculapius of Goa" [7]. Furthermore, in 1785, the physician Francisco Barroso da Silva continued to practice and teach conventional medicine at the Royal Hospital of Goa, although the poor training of Indian physicians contributed to the high mortality rates in Portuguese India [8].

In historical terms, Ignácio Caetano AfonsoPão was a Brahmin and chief physician of Portuguese India (XVIII century) who used aloe, ginger, opium, sandalwood medicinal plants from India used in Ayurveda [9] - to cure diseases of the Eastern Indies (such as military fever) along with allopathic medication.In 1794, due to the high mortality of Portuguese troops [10], AfonsoPão wrote a manuscriptentitled "Descriptions and Virtues of Medical Roots"on local medical knowledge [11]. Some Indian medicinal roots, such as the "Indian snake root"known as «Rauwolfiaserpentina»and shown in Figure 1, were used for snake bites (sedative), Asian cholera, psychosis treatment, and rheumatism, and so they were very important for Portuguese medicine in India [12]. 


\section{International Journal of Science and Research (IJSR) \\ ISSN: 2319-7064}

ResearchGate Impact Factor (2018): 0.28 | SJIF (2018): 7.426

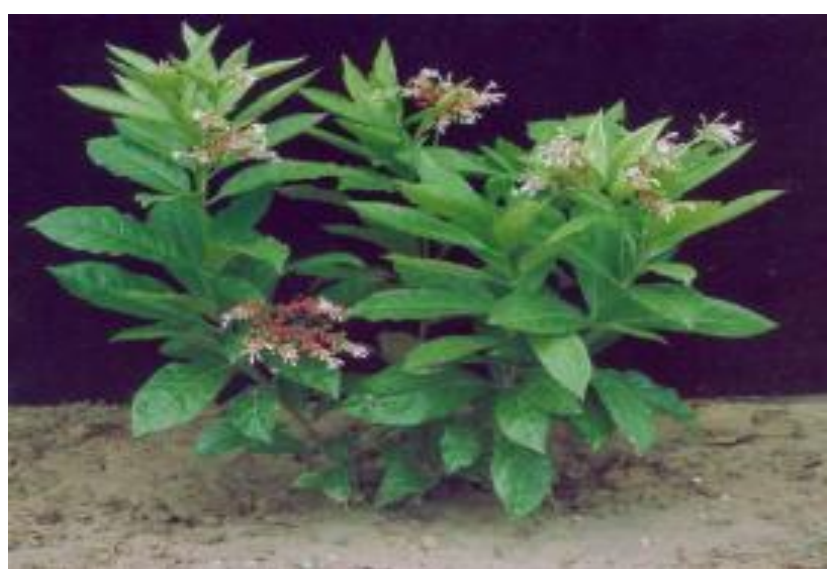

Figure 1: "Indian Snake root" (known as «Rauwolfia Serpentine»)

Photo Source -Courtesy ofNational Council of Medicinal Plants of India (NMPB), department AYUSH

\section{Conclusions}

In the XVIII century, the physician Ignácio Caetano AfonsoPão was an example of the influence of Eastern Medicine on Portuguese medicine [13]. It was also a successful case of dialogue and exchange of information between Indian and Portuguese physicians [14], when most of Indian physicians did not share their medical knowledge with other people [15]. This fact allowed AfonsoPão to practice conventional medicine together with Ayurveda, contributing to a more holistic and effective medical practice in the treatment of patients, in the Portuguese India (XVIII century) [16].

\section{Acknowledgements}

Paulo Nuno Martins would like to thank the National Council of Medicinal Plants of India (NMPB), department AYUSH, for the authorization given for the display of Figure 1 entitled "Indian Snake root" (known as «Rauwolfia Serpentine»).

\section{References}

[1] Pandya, S. 1982. Medicine in Goa - a former Portuguese territory.Journal of Postgraduate Medicine, 28(3):123-148.

[2] Lopes, Maria de Jesus. 2006. O Império Oriental. EditoraEstampa.

[3] Danvers, Frederick. 1894. The Portuguese in India: a history of the rise and decline of their Eastern empire. W.H.Allen\&Co.

[4] Mukhopadhyaya, Girindranath. 2003. History of Indian Medicine. MunshiramManoharlal Publishers.3 Vols.

[5] Zysk, Kenneth. 1993. Religious Medicine: The History and Evolution of Indian Medicine. Transaction Publishers.

[6] Bastos, Cristiana. 2010. Medicine, Colonial Order and Local Action in Goa. In: Digby, A.; Waltraud, E.; Muhkarji, P. (Ed.). Crossing Colonial Historiographies: Histories of Colonial and Indigenous Medicines in Transnational Perspective.pg.185-212.
[7] De Figueiredo, J. Pacheco. 1978. Goan doctors in the Portuguese speaking world. In: John CorreiaAfonso (Ed.), International Seminar on Indo-Portuguese History, Pgs. 33-34.

[8] Gracias, Fátima. 1994. Health and Hygiene in colonial Goa (1510-1961). Concept Publishing House.

[9] Walker, Timothy. 2002. Evidence of the use of Ayurvedic Medicine in the medical Institutions of Portuguese India (1680-1830). In: Salema, A. (Ed.). Ayurveda at the Crossroads of Care and Cure, pg. 74104.

[10] Pereira, Magnus. 2017. New plants that scholars do not know: scientific exploration of nature in Portuguese East Asia, 1768-1808. História, Ciências, SaúdeManguinhos, 24(3): 665-685.

[11]Pão, Ignácio. 1794. Discripçoens e Virtudes das Raízes Medicinaes. HAG (HistoricalArchiveof Goa).

[12] Walker, Timothy. 2011. Stocking Colonial Pharmacies: Commerce in the South Asian Indigenous Medicine from their Native Source in the Portuguese Estado da Índia. In: Mukherjee, R. (Ed.). Network in the First Global Age (1400-1800), pg. 141-170.

[13] Walker, Timothy. 2001. Remedies from the Carreira da Índia: Asian Influences on Portuguese Medicine during the Age of Enlightenment, Portuguese Studies Review 9:170-193.

[14] Walker, Timothy. 2008. Acquisition and Circulation of Medical Knowledge within the Early Modern Portuguese Colonial Empire. In: Bleichmar, D.; De Vos, P.; Huffine, K.; Sheehan, K. (Ed.). Science in the Spanish and Portuguese Empire (1500-1800), pg.247270.

[15]Bracht, Fabiano. 2016. Condicionantes sociais e políticos nos processos de produção de conhecimento. O caso da Índia portuguesa do século XVIII. In: Polónia, A.;Bracht, F. et al (Org.). Ciência e poder na primeira Idade Global, pg. 94-121.

[16] Walker, Timothy. 2011a. Supplying simples for the Royal Hospital: an Indo-Portuguese medicinal garden in Goa (1550-1830). In: Jarnagin, L.(Ed.). Portuguese and Luso-Asian legacies in Southeast Asia.

\section{Author Profile}

Paulo Nuno Martins is a Chemical Engineer from Instituto Superior Técnico, University of Lisbon and a PhD in History and Philosophy of Science from Faculty of Sciences and Technology, New University of Lisbon. The author has studied for four years Oriental languages and culture (Indian, Chinese, Japanese, Arabic) and he is currently a researcher in History of Science at Interuniversity Center for History of Science and Technology, CIUHCT, Portugal, (http://orcid.org/0000-0002-2670-3172). He is a member of CTEC (Transdisciplinary Center of Consciousness Studies), Porto and CIRET (Centre International de Recherchesetd ÉtudesTransdisciplinaires), Paris. 